\title{
Lᄂ 論文
}

\section{アンモニア性パラジウム塩水溶液の水素還元 ${ }^{*}$}

\author{
安田拓 ${ }^{1}$ 木 内 弘 道 $^{2}$
}

\section{Hydrogen Reduction of Ammoniacal Palladous Salt Solution}

by Takuo YASUDA ${ }^{1}$ and Hiromichi KIUCHI ${ }^{1}$

1. Faculty of Engineering, Hokkaido University, Kita - ku, Sapporo 060

\begin{abstract}
Reduction of palladium from ammoniacal aqueous solution with hydrogen in a gas bubbling batch reactor or an autoclave was investigated. Runs were carried out for a range of temperatures from $293 \mathrm{~K}$ to $353 \mathrm{~K}$ and hydrogen partial pressures from $0.25 \times 10^{5} \mathrm{~Pa}$ to $10.0 \times 10^{5} \mathrm{~Pa}$.

The form of the palladium complex ion in the solution was found to be $\mathrm{Pd}\left(\mathrm{NH}_{3}\right)_{4}{ }^{2+}$ under the $\mathrm{pH}$ conditions from 6.2 to 10.0, resulting in its stability in the reactant solution for a wide range of $\mathrm{pH}$.

Apparent reaction rates showed a Oth-order dependence on the palladium concentration for all values of temperature examined. The rate was linearly dependent on the partial pressure of hydrogen at lower pressures and was almost independent of the partial pressure of hydrogen at higher pressures. The activation energy given was approximately $41 \mathrm{~kJ} \cdot \mathrm{mol}^{-1}$. Assuming that the Langmuir-Hinshelwood mechanism was applicable to the reaction in the present study, the rate determining step of the reaction was presumed to be the desorption step of $\mathrm{NH}_{3}$ (i. e., reaction product) from the surface of the palladium produced.
\end{abstract}

KEY WORDS : Ammoniacal Palladous Salt Solution, Reduction Rate of Hydrogen, Palladium Ammine Complex Ion, Desorption Control, Langmuir-Hinshelwood Mechanism

\section{1. 緒}

金属塩水溶液から水素還元により目的金属を回収する方法につい ては多くの研究例が報告されているが, ニッケル, コバルト, 銅の 回収を中心に主としてアンモ二ア性水溶液を用いて水素加圧還元す る方法が用いられており ${ }^{122)}$ ，実操業においてあアンモ二ア性水溶 液が採用されている ${ }^{3)}$ 。前報 ${ }^{4)}$ では塩化パラジゥム酸水溶液の還元 についてこれを速度論的に検討した。しかしながら，アンモニア性 パラジゥム塩水溶液からの水素還元法によるパラジウム微粉末の製 造に関する研究は例がなく, 著者ら ア性溶液から水素還元により単分散球状パラジゥム微粉末を製造で きることが見出されているものの, 還元反応の速度論的研究につい ては未だ不明である。

そこで本研究ではアンモニアを添加したパラジゥムのアンミン錯 イオンの水素還元反応実験を行い, 還元反応速度および機構につい て検討した。

\section{2. 実験装置および実験方法}

本実験で用いた塩化パラジゥム酸水溶液の原液は田中貴金属工業 (株)加貸与されたもので，パラジゥム濃度は $15,220 \mathrm{wt} \%$ である。 実験には, これを蒸留水で希釈した後, 市販特級試薬を加えて $\mathrm{pH}$ と溶液濃度を調整した水溶液 $1.50 \times 10^{-4} \mathrm{~m}^{3}$ を反応試料として用 いた。還元ガスとしては市販のボンベからの $\mathrm{N}_{2}-\mathrm{H}_{2}$ 混合ガスを用

* 1994 年 3 月 17 日受付 8 月 5 日受理

1. 学生会員 北海道大学大学院生 博士課程金属工学専攻

2. 正会員 工博 北海道大学助教授 工学部金属工学科

キーワード：アンモニア性パラジゥム塩水溶液, 水素還元速度, パラジゥム アンミン錯イオン, 脱離律速, Langmuir-Hinshelwood 機構
いた。

実験装置は常圧水素ガス流通式および水素加圧式回分反応装置で あり，その概略図をFig. 1 に示す。ガス流通式回分反応装置（Fig. (a)）の操作手順については前報 ${ }^{4)}$ で詳述した通りである。水素加 圧式回分反応装置 (Fig. (b)) の反応容器(1)は内容積約 $8.0 \times 10^{-4}$ $\mathrm{m}^{3}$ のガラス製であり, 靦拌はインペラ(7)により, 加熱はヒータ(2) により行った。実験に際してはまず, 反応容器内を $\mathrm{N}_{2}$ ガスに置換 後, $5 \times 10^{5} \mathrm{~Pa}$ まで加圧して昇温し, 所定の温度に安定したとこ ろで摜挥を開始するとともに水素ガスの所定圧をリサーバ(9)から 加圧する。還元反応の進行とともに反応容器内の水素が消費される が，その消費分はリサーバから補給されて容器内は常に所定圧に維 持されている。一方，リサーバの水素圧は消費水素の補給とともに 減少するのでその変化をプレッシャートランスデューサ(8)によっ て測定し反応曲線を取得した。本実験における反応温度は $293 \mathrm{~K} \sim$ $353 \mathrm{~K}$, 混合ガスの水素分圧は $0.25 \times 10^{5} \sim 10.0 \times 10^{5} \mathrm{~Pa}$ ，パラ ジゥム初期濃度は $0.01 \sim 0.10 \mathrm{kmol} \cdot \mathrm{m}^{-3}$ である。還元率は, 吸引 ろ過により, 生成パラジゥム粉末を分離後, ろ液中の残存パラジゥ ム量を ICP 発光分光分析装置 (セイコー電子工業(株)製 SPS 1100) により定量し，算出した。なお，溶液の可視・紫外線吸収スペクト ルの測定には日立自記分光光度計 320 を使用した。

\section{3，実験結果と考察}

\section{$3 \cdot 1$ 試料溶液の調製}

本研究に使用した試料溶液は, 上述の塩化パラジゥム酸水溶液原 液（ $\mathrm{H}_{2} \mathrm{PdCl}_{4}: \mathrm{pH}=1.1 ）$ にアンモニアを添加して調製したもの である。Fig. 2 はパラジゥム濃度が $0.05 \mathrm{kmol} ・ \mathrm{~m}^{-3}$ の塩化パラジ ウム酸水溶液にアンモニアを添加した場合に生成するパラジゥムの アンミン錯化合物中のパラジゥム量と溶液 $\mathrm{pH}$ の関係を示している。 
(a)

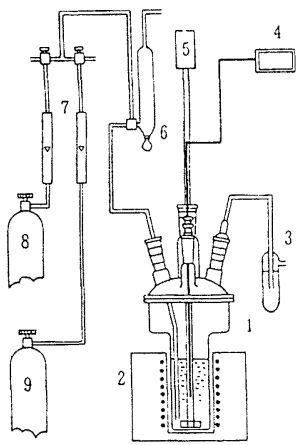

(b)

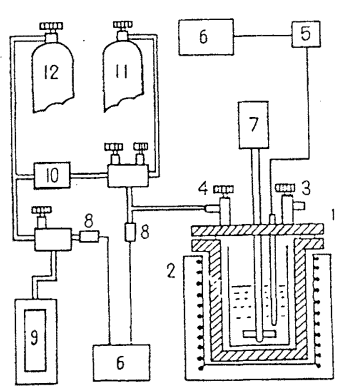

1. reactor

2. heater

3. trap

4. thermometer

5. impeller

6. soapfilm flowmeter

7. rotameter

8. $\mathrm{N}_{2}$ cylinder

9. $\mathrm{H}_{2}$ cylinder

Fig. 1 Schematic illustration of experimental apparatus. (a) gas bubbling batch reactor, (b) autoclave

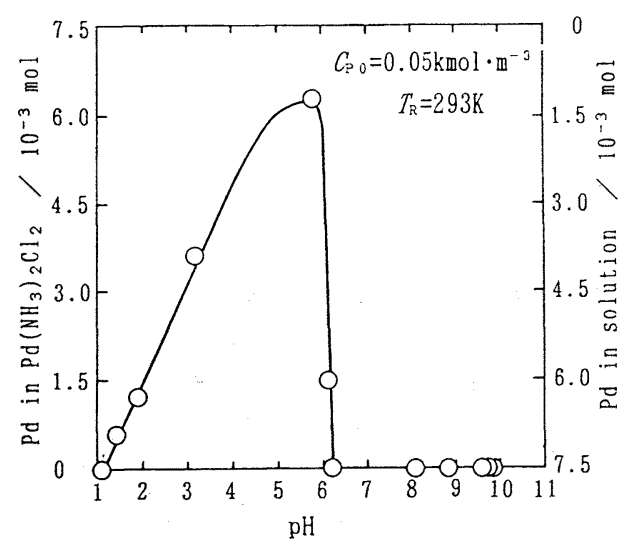

Fig. 2 Relationship between $\mathrm{Pd}$ in $\mathrm{Pd}\left(\mathrm{NH}_{3}\right)_{2} \mathrm{Cl}_{2}$ and pH.

ここで, 錯化合物中のパラジゥム量は, 溶液のパラジゥム初期濃度 $\left(0.05 \mathrm{kmol} \cdot \mathrm{m}^{-3}\right)$ から, アンモニアを添加して錯化合物を生成さ せた溶液を吸引ろ過して得たろ液のパラジゥム濃度を減じて求めた。 また，この錯化合物は X 線回折結果からジクロロアンミンパラジ ウム (II)塩化物, すなわち $\mathrm{Pd}\left(\mathrm{NH}_{3}\right)_{2} \mathrm{Cl}_{2}$ と同定された。図から, $\mathrm{pH}$ の増加とともに錯化合物の量が増加するが, $\mathrm{pH}$ が約 5.5 で最 大值に達した後, 再溶解のために急速に隇少し, $\mathrm{pH}$ が約 6.2 で完 全に消失することがわかる。また, 気相からは $\mathrm{Cl}_{2}$ も $\mathrm{HCl}$ あ検出 されなかった。

Fig. 3 に, パラジゥム濃度が $0.05 \mathrm{kmol} ・ \mathrm{~m}^{-3}, \mathrm{pH}$ が 6.2 および 10.0 の 2 種類の試料溶液の可視・紫外線吸収スペクトルを示す。図 を見ると, 両溶液についての吸収スペクトルはほぼ一致しており, いずれの溶液む錯イオンの構造が同一であることを示している。 Table $1^{6)}$ には各種パラジゥム錯イオンの波長 $\lambda$, 波数 $\sigma$ およびモ 儿吸光係数 $\varepsilon$ を示す。上記の両溶液のスペクトルから得られる $\lambda$ お よび $\varepsilon$ はそれぞれ $295 \mathrm{~nm}$ および 200 であり，これらは表中の $\mathrm{Pd}\left(\mathrm{NH}_{3}\right)_{4}{ }^{2+}$ についての値と一致する。したがって両溶液のパラ ジゥム錯イオンは $\mathrm{Pd}\left(\mathrm{NH}_{3}\right)_{4}{ }^{2+}$ であり, $\mathrm{pH}$ が 6.2 から 10.0 の範

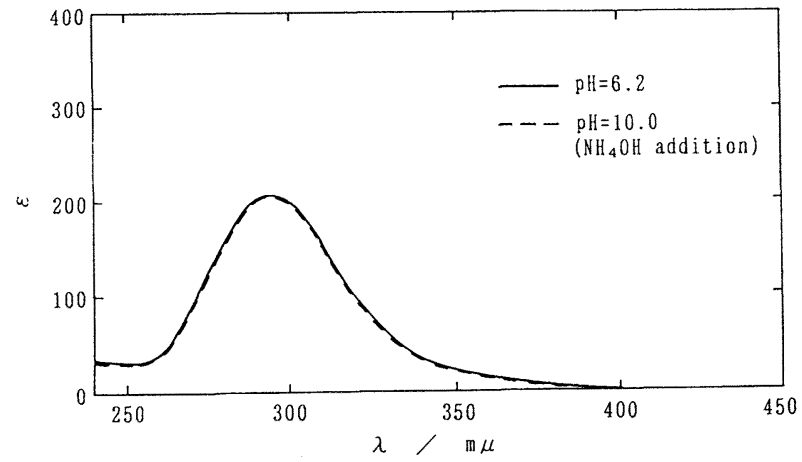

Fig. 3 Effect of $\mathrm{pH}$ on UV spectrum of Pd solution.

Table 1 Wavelengths $\lambda$ in $\mathrm{m} \mu$, wavenumbers $\sigma\left(1000 \mathrm{~cm}^{-1}\right)$ and molar extinction coefficients $\varepsilon$ of the first maximum of palladium(II) complexes ${ }^{6}$.

\begin{tabular}{c|c|c|c}
\hline \hline & $\lambda$ & $\sigma$ & $\varepsilon$ \\
\hline $\operatorname{Pd}\left(\mathrm{H}_{2} \mathrm{O}\right)_{4}{ }^{2+}$ & 379 & 26.4 & 78 \\
$\operatorname{Pd}\left(\mathrm{NH}_{3}\right)\left(\mathrm{H}_{2} \mathrm{O}\right)_{3}{ }^{2+}$ & 360 & 27.8 & 130 \\
$\operatorname{Pd}\left(\mathrm{NH}_{3}\right)_{2}\left(\mathrm{H}_{2} \mathrm{O}\right)_{2}{ }^{2+}$ & 341 & 29.3 & 215 \\
$\operatorname{Pd}\left(\mathrm{NH}_{3}\right)_{3}\left(\mathrm{H}_{2} \mathrm{O}\right)^{2+}$ & $\sim 317$ & $\sim 31.6$ & - \\
$\operatorname{Pd}\left(\mathrm{NH}_{3}\right)_{4}{ }^{2+}$ & 295 & 33.9 & 200 \\
\hline
\end{tabular}

囲でこれが安定に存在することが明らかである。

上の結果から，溶液調製中に起る反応は次のようなものと推察さ れる。すなわち $\mathrm{PdCl}_{4}{ }^{2-}$ 溶液にアンモニアを添加すると，

$\mathrm{PdCl}_{4}{ }^{2-}+2 \mathrm{NH}_{4} \mathrm{OH} \rightarrow \mathrm{Pd}\left(\mathrm{NH}_{3}\right)_{2} \mathrm{Cl}_{2}+2 \mathrm{Cl}^{-}+2 \mathrm{H}_{2} \mathrm{O}$

により, $\mathrm{Pd}\left(\mathrm{NH}_{3}\right)_{2} \mathrm{Cl}_{2}$ が生成し, その量はアンモニアの添加量と ともに増加する。さらに過剩に添加すると,

$\mathrm{Pd}\left(\mathrm{NH}_{3}\right)_{2} \mathrm{Cl}_{2}+2 \mathrm{NH}_{4} \mathrm{OH} \rightarrow \mathrm{Pd}\left(\mathrm{NH}_{3}\right)_{4}{ }^{2+}+2 \mathrm{Cl}^{-}+2 \mathrm{H}_{2} \mathrm{O}$

により $\mathrm{Pd}\left(\mathrm{NH}_{3}\right)_{2} \mathrm{Cl}_{2}$ は再溶解し, $\mathrm{Pd}\left(\mathrm{NH}_{3}\right)_{4}{ }^{2+}$ を生成するもの と考えられる。本研究では以下, $\mathrm{Pd}\left(\mathrm{NH}_{3}\right)_{4}{ }^{2+}$ が安定に存在する $\mathrm{pH}=6.2$ 以上の溶液について反応実験を行った。

\section{$3 \cdot 2$ 還元反応および反応速度機構}

$3 \cdot 2 \cdot 1$ 還元反応 Fig. 4 は, $\mathrm{pH}$ が 6.5, パラジゥム初 期濃度 $\left(C_{\mathrm{P}_{0}}\right)$ が $0.05 \mathrm{kmol} \cdot \mathrm{m}^{-3}$ の溶液を反応試料として, 水素 分圧 $\left(P_{\mathrm{H}_{2}}\right)$ が $1.0 \times 10^{5} \mathrm{~Pa}$, 反応温度 $\left(T_{\mathrm{R}}\right)$ が $293 \sim 353 \mathrm{~K}$ の条 件で還元反応を行ったときの還元率 $\left(X_{\mathrm{R}}=\left(C_{\mathrm{P}_{0}}-C_{\mathrm{P}}\right) / C_{\mathrm{P}_{0}}\right)$ と還 元時間 $\left(t_{\mathrm{R}}\right)$ の関係を示したものである。ただし $C_{\mathrm{P}}$ はパラジゥム 濃度である。 $T_{\mathrm{R}}>313 \mathrm{~K}$ の場合， $X_{\mathrm{R}}$ は時間とともにほぼ直線的 に増加し, 直線の勾配は $T_{\mathrm{R}}$ が高いほど大きい。これに対して $T_{\mathrm{R}}$

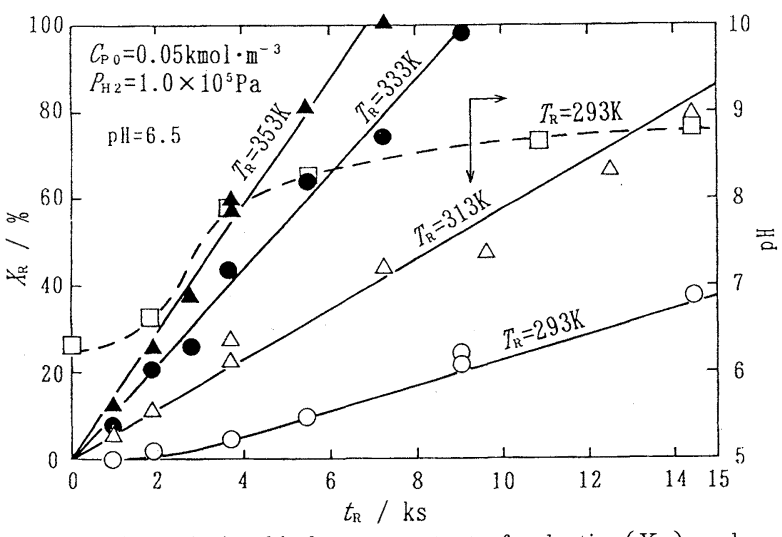

Fig. 4 Relationship between extent of reduction $\left(X_{R}\right)$ and reduction time $\left(t_{R}\right)$ at various temperatures. 


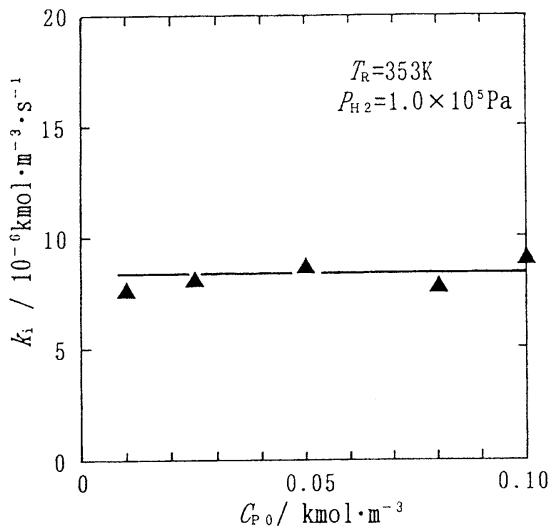

Fig. 5 Relationship between apparent rate constants $\left(k_{\mathrm{i}}\right)$ and initial $\mathrm{Pd}$ concentrations $\left(C_{\mathrm{P}_{0}}\right)$.

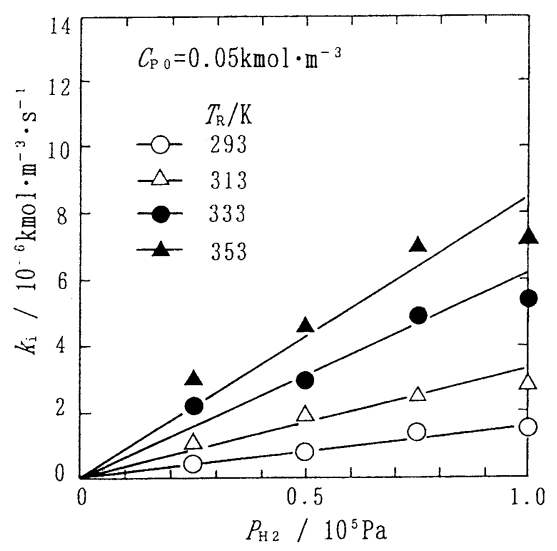

Fig. 6 Relationship between apparent rate constants $\left(k_{\mathrm{i}}\right)$ and partial pressure of hydrogen $\left(P_{\mathrm{H}_{2}}\right)$ at various temperatures.

$=293 \mathrm{~K}$ の場合, 反応開始から $t_{\mathrm{R}}=1.8 \mathrm{ks}$ まで誘導期が現れ, こ の間, $\mathrm{pH}$ はほとんど変化しない。誘導期を過ぎると $T_{\mathrm{R}}>313 \mathrm{~K}$ の場合と同様, $X_{\mathrm{R}}$ は $t_{\mathrm{R}}$ とともに直線的に増大し, 還元反応の進 行による $\mathrm{OH}^{-}$の増加に伴って $\mathrm{pH}$ は増加する。Flg. 5 は $T_{\mathrm{R}}=$ $353 \mathrm{~K}$ における見かけの反応速度 $\left(k_{\mathrm{i}}\right)$ の $C_{\mathrm{P}_{0}}$ に対する依存性を示 したあのである。図から， $k_{\mathrm{i}}$ は $C_{\mathrm{P}_{0}}$ にはほとんど依存せず，約 8 $\times 10^{-6} \mathrm{kmol} \cdot \mathrm{m}^{-3} \cdot \mathrm{s}^{-1}$ であることがわかる。さらに Fig. 6 は $\mathrm{H}_{2}$ と $\mathrm{N}_{2}$ の混合比を変えた実験から， $k_{\mathrm{i}}$ の $P_{\mathrm{H}_{2}}$ に対する依存性を種々 の反応温度で検討したものである。これをみると，いすれの温度に おいても $k_{\mathrm{i}}$ が $P_{\mathrm{H}_{2}}$ の一次に依存することがわかる。

Fig. 7 は反応挙動に及ぼす固体パラジゥム seed 添加の影響を示 している。使用したパラジウム seed は平均粒径 $1.1 \mu \mathrm{m}$, BET 比 表面積 $8.80 \times 10^{2} \mathrm{~m}^{2} \cdot \mathrm{kg}$ の単分散球状粒子であり, その添加量は $8.0 \times 10^{-4} \mathrm{~kg}$ である。同図から明らかなように seed 添加を行う と反応速度の増大が見られ，その速度は $293 \mathrm{~K}$ および $313 \mathrm{~K} に お ~$ いてそれぞれ無添加の場合の約 1.8 倍および約 2.8 倍となる（Fig. (a))。また， seed 添加による還元率の上昇と seed 添加は量の間に は比例関係が得られた（Fig. (b))。すなわち本溶液の還元反応は 固体パラジゥム表面で進行する固液界面反応であるこが確認された。

\section{$3 \cdot 2 \cdot 2$ 反応速度と反応機構 $\mathrm{Pd}^{2+}$ の水素による還元反} 応 ;

$\mathrm{Pd}^{2+}+\mathrm{H}_{2} \rightarrow \mathrm{Pd}^{0}+2 \mathrm{H}^{+}$

の回分反応器における物質収支は,

$$
-\frac{\mathrm{d}\left[\mathrm{Pd}^{2+}\right]}{\mathrm{d} t_{\mathrm{R}}}=k\left[\mathrm{Pd}^{2+}\right]^{m}\left[\mathrm{H}_{2}\right]^{n}
$$

と書かれる。ここで $k$ は反応速度定数, $m, n$ は反応の次数である。 本実験条件下では上記の還元反応はパラジゥム濃度変化には依存し
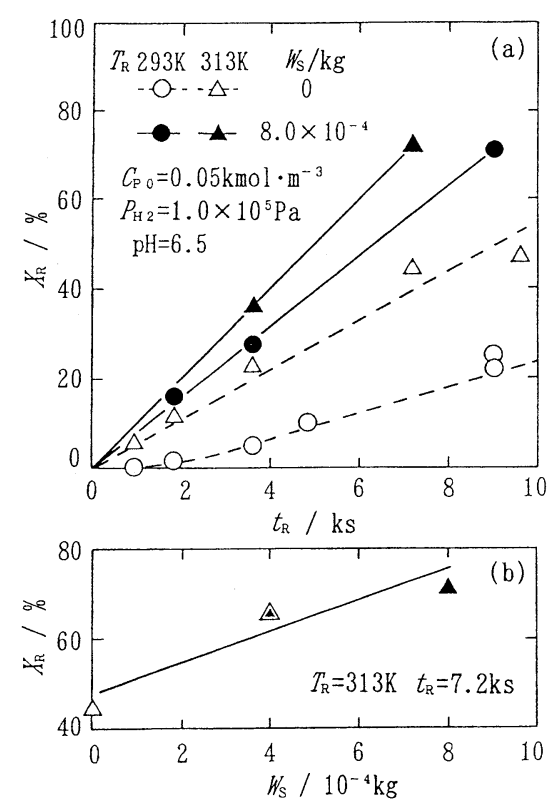

Fig. 7 Effects of Pd seed additions (a) on reduction profiles and (b) on reduction extent at $t_{\mathrm{R}}=7.2 \mathrm{ks}$.

ないので $m=0$ である (Fig. 5)。また, 反応温度が低い（ $T_{\mathrm{R}}=$ $293 \mathrm{~K})$ 場合は反応の誘導期が現れるが, これが水素ガスの溶解が 平衡に達するために要する時間と考え, $T_{\mathrm{R}}$ が高い場合には水素が 反応初期加溶解平衡に達していると考えると(1)式は $k_{\mathrm{i}}$ を見掛け の反応速度定数として

$$
-\frac{\mathrm{d}\left[\mathrm{Pd}^{2+}\right]}{\mathrm{d} t_{\mathrm{R}}}=k_{1}\left[\mathrm{H}_{2}\right]+k_{\mathrm{i}}
$$

と表すことができる。そこで実験から決定した $k_{\mathrm{i}}$ と温度依存性を 考慮した水素溶解度 ${ }^{7)}$ から真の反応速度定数 $k_{1}$ を算出すると Table 2 のようになり， $k_{1}$ の Arrhenius プロット（Fig. 8）から見 掛けの活性化エネルギー $\left(E_{\mathrm{A}}\right)$ は $41.0 \mathrm{~kJ} \cdot \mathrm{mol}^{-1}$ と求まる。

ここでアンモニア性パラジゥム塩水溶液の水素還元反応の素反応 課程はつぎのようなものと考えられる；

$\mathrm{Pd}\left(\mathrm{NH}_{3}\right)_{4}{ }^{2+} \rightarrow \mathrm{Pd}^{2}+4 \mathrm{NH}_{3}$

$\mathrm{Pd}^{2+}+\mathrm{H}_{2} \rightarrow \mathrm{Pd}^{0}+2 \mathrm{H}^{+}$

他方, 酸性塩化パラジゥム酸水溶液の場合も同様にパラジゥムイオ ンに配位する $\mathrm{Cl}^{-}$を考慮すると，

$\mathrm{PdCl}_{4}{ }^{2-} \rightarrow \mathrm{Pd}^{2}+4 \mathrm{Cl}^{-}$

$\mathrm{Pd}^{2+}+\mathrm{H}_{2} \rightarrow \mathrm{Pd}^{0}+2 \mathrm{H}^{+}$

と書き表すことができる。すなわち $\mathrm{PdCl}_{4}{ }^{2-}$ の場合は還元反応に より $\mathrm{Cl}^{-}$が生成するが, $\mathrm{Pd}\left(\mathrm{NH}_{3}\right)_{4}{ }^{2+}$ の場合は $\mathrm{NH}_{3}$ が生成する。 前報 ${ }^{4)}$ で明らかにしたように, 酸性溶液の場合の $E_{\mathrm{A}}$ は反応の前半 課程では $25.1 \mathrm{~kJ} \cdot \mathrm{mol}^{-1}$, 後半課程では $16.2 \mathrm{~kJ} \cdot \mathrm{mol}^{-1}$ と低い值で あり, 反応が液相境膜内物質移動律速, とくに反応の前半では水素 拡散律速となる。これに対し, 本実験の場合の $E_{\mathrm{A}}$ は $41.0 \mathrm{~kJ} ・$ $\mathrm{mol}^{-1}$ であり, この結果だけから還元反応の律速段階を決定する ことは難しい。

Fig. 9 は, アンモニア性溶液と酸性溶液の反応速度を比較したも

Table 2 Apparent rate constants $\left(k_{\mathrm{i}}\right)$ and modified rate constants $\left(k_{1}\right)$.

\begin{tabular}{c|c|c|c|c}
\hline \hline$T_{\mathrm{R}}^{-1} / 10^{-3} \mathrm{~K}^{-1}$ & 2.83 & 3.00 & 3.19 & 3.41 \\
\hline$k_{\mathrm{i}} / 10^{-6} \mathrm{kmol} \cdot \mathrm{m}^{-3} \cdot \mathrm{s}^{-1}$ & 7.27 & 5.39 & 2.86 & 1.45 \\
\hline$\left[\mathrm{H}_{2}\right] / 10^{-4} \mathrm{kmol} \cdot \mathrm{m}^{-3}$ & 3.79 & 5.76 & 6.83 & 7.95 \\
\hline$k_{1} / 10^{-2} \mathrm{~s}^{-1}$ & 1.92 & 0.94 & 0.42 & 0.18 \\
\hline
\end{tabular}




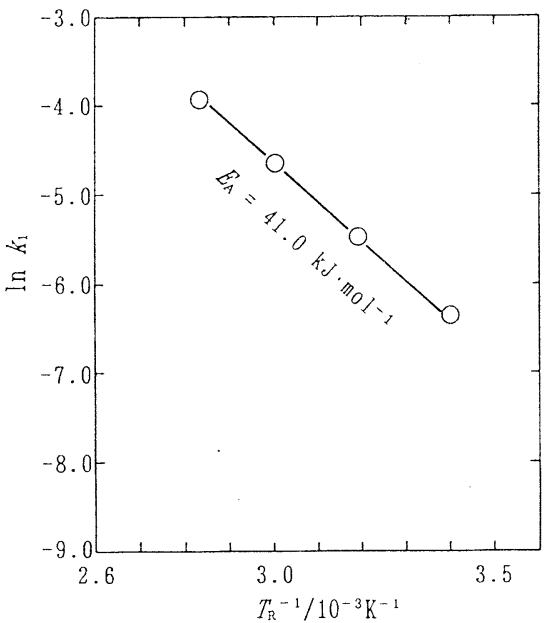

Fig. 8 Arrhenius plots of reaction rate constants $\left(k_{1}\right)$.

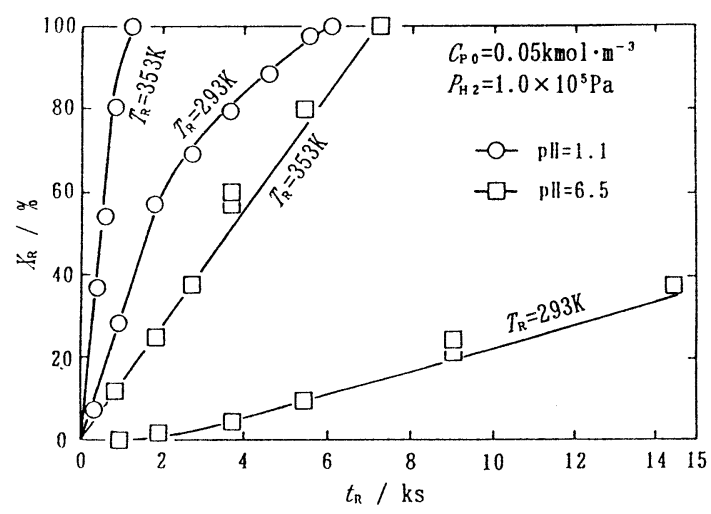

Fig. 9 Relationship between extent of reduction $\left(X_{\mathrm{R}}\right)$ and reduction time $\left(t_{\mathrm{R}}\right)$ for acid solution $\left(\mathrm{PdCl}_{4}{ }^{2-}\right)$ and ammoniacal solution $\left(\mathrm{Pd}\left(\mathrm{NH}_{3}\right)_{4}{ }^{2+}\right)$.

のである。図から前者の反応速度は後者に比較して著しく小さく， 例えば $T_{\mathrm{R}}=353 \mathrm{~K}$ では約 $3 / 20, T_{\mathrm{R}}=293 \mathrm{~K}$ では約 $2 / 25$ であるこ. とが明らかであり,このような反応速度の大きな差は液相における 水素拡散律速ではないことを示唆する。また, 坂野ら ${ }^{8)}$ はアンモ二 ア性硫酸コバルト水溶液の水素還元反応に関する研究において常温, 水素分圧 $5.0 \times 10^{6} \mathrm{~Pa}$ における水溶液中の水素溶解量とアンモ二 ア濃度の関係について言及し, 溶液中のアンモニア濃度が水素溶解 度に与える影響はわずかであると指摘している。すなわち本研究の 場合あ同様にアンモニアの添加が水素の溶解度に影響を与えないむ のと仮定すると液相における水素の拡散律速は否定される。また, Fig. 4 および Fig. 5 から明らかなように本溶液の反応はパラジゥ ムイオン濃度に依存しない 0 次反応であること, および活性化エネ ルギーが化学反応律速を想定するには低すぎることから表面反応は 総括反応の律速段階とはならない。

他方, 坂野ら ${ }^{8)}$ はアンモニア性硫酸コバルト水溶液の水素還元反 応の活性化エネルギーが $31.59 \mathrm{~kJ} \cdot \mathrm{mol}^{-1}$ であり, この場合は固体 コバルト表面での水素の解離吸着が律速となることを示唆しており, 本溶液の反応においても上述の結果からパラジゥム固体表面におけ る反応種あるいは生成種の吸着・脱離が律速となっているものと考 えられる。

そこで $P_{\mathrm{H}_{2}}=1.0 \times 10^{5} \mathrm{~Pa}$ 以上における反応速度と水素圧力の 関係についての知見を得るため水素加圧式回分反応装置を用いて加 圧還元実験を行った。

Fig. 10 (a), (b)はそれぞれ $\mathrm{PdCl}_{4}{ }^{2-}$ 溶液抒よび $\mathrm{Pd}\left(\mathrm{NH}_{3}\right)_{4}{ }^{2+}$ 溶液をオートクレーブを用いて加圧還元を行った場合の $k_{\mathrm{i}}$ と $P_{\mathrm{H}_{2}}$
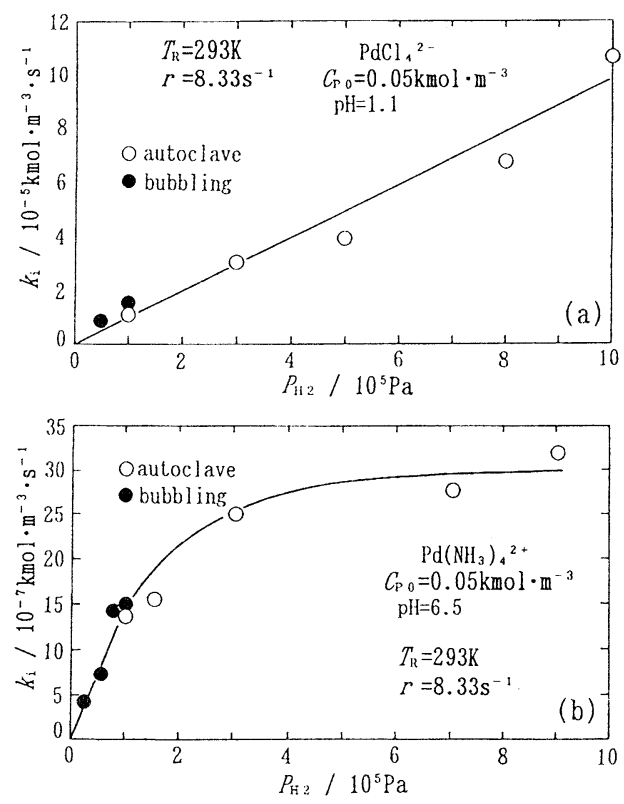

Fig. 10 Relationship between apparent rate constants $\left(k_{\mathrm{i}}\right)$ and partial pressure of hydrogen $\left(P_{\mathrm{H}_{2}}\right)$ at $293 \mathrm{~K}(\mathrm{a})$ for acid solution $\left(\mathrm{PdCl}_{4} 2-\right.$ ) (b) for ammoniacal solution $\left(\mathrm{Pd}\left(\mathrm{NH}_{3}\right)_{4}^{2+}\right)$.

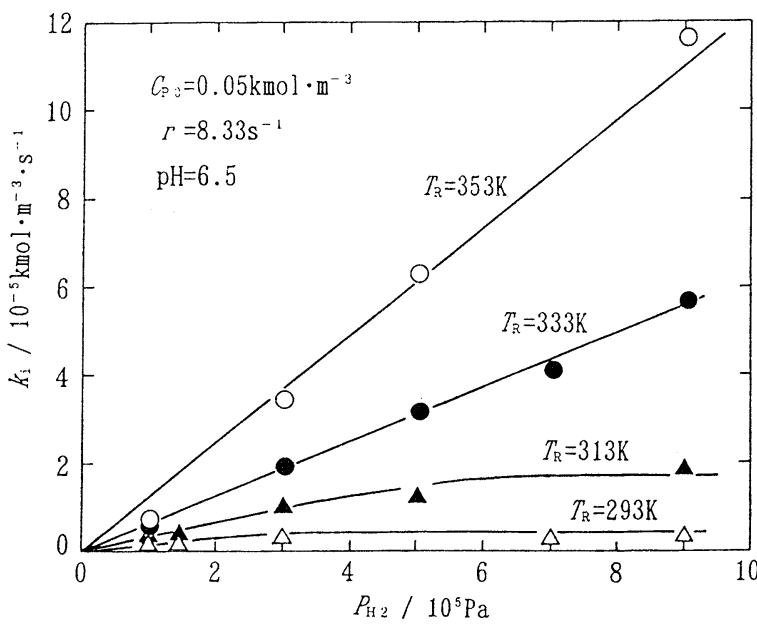

Fig. 11 Relationship between apparent rate constants $\left(k_{\mathrm{i}}\right)$ and partial pressure of hydrogen $\left(P_{\mathrm{H}_{2}}\right)$ at various temperatures for ammoniacal solution $\left(\mathrm{Pd}\left(\mathrm{NH}_{3}\right)_{4}{ }^{2+}\right)$.

の関係を示している。図中には水素ガス流通式回分反応装置を用い て $P_{\mathrm{H}_{2}}=1.0 \times 10^{5} \mathrm{~Pa}$ として還元を行った場合の $k_{\mathrm{i}}$ 值むbubbling として併記した。この結果が示すように $\mathrm{PdCl}_{4}{ }^{2-}$ 溶液の場 合 (Fig. (a)) は $P_{\mathrm{H}_{2}}$ が $0 \sim 10.0 \times 10^{5} \mathrm{~Pa}$ の全 $P_{\mathrm{H}_{2}}$ 範囲におい て $k_{\mathrm{i}}$ と $P_{\mathrm{H}_{2}}$ の間に直線関係が見られる。しかし $\mathrm{Pd}\left(\mathrm{NH}_{3}\right)_{4}{ }^{2+}$ 溶 液の場合 (Fig. (b)), $P_{\mathrm{H}_{2}}>1.0 \times 10^{5} \mathrm{~Pa}$ 範囲において $k_{\mathrm{i}}$ と $P_{\mathrm{H}_{2}}$ の間に比例関係が成立しない, すなわち $P_{\mathrm{H}_{2}}>1.0 \times 10^{5} \mathrm{~Pa}$ の範 囲では $P_{\mathrm{H}_{2}}$ が増加すると徐々に $k_{\mathrm{i}}$ の上昇率を減じ, $P_{\mathrm{H}_{2}}$ 約 $4.0 \times$ $10^{5} \mathrm{~Pa}$ を超えると $k_{\mathrm{i}}$ はほぼ一定となる。

Fig. 11 は Pd $\left(\mathrm{NH}_{3}\right)_{4}{ }^{2+}$ 溶液の還元における $k_{\mathrm{i}}$ の水素分圧依存 性を種々の反応温度で検討したものである。これを見ると $T_{\mathrm{R}}=$ $353 \mathrm{~K}$ および $T_{\mathrm{R}}=313 \mathrm{~K}$ の場合は $k_{\mathrm{i}}$ と $P_{\mathrm{H}_{2}}$ の間に直線関係があ るが $T_{\mathrm{R}}=313 \mathrm{~K}$ の場合は Fig. 10(b)で説明した $T_{\mathrm{R}}=293 \mathrm{~K}$ にお ける $k_{\mathrm{i}}$ の $P_{\mathrm{H}_{2}}$ 依存性と同様, $P_{\mathrm{H}_{2}}$ の大きな範囲 $\left(P_{\mathrm{H}_{2}}>5.0 \times\right.$ $\left.10^{5} \mathrm{~Pa}\right)$ で $k_{\mathrm{i}}$ の $P_{\mathrm{H}_{2}}$ に対する依存性が著しく小さくなっている。

ここで $\mathrm{Pd}\left(\mathrm{NH}_{3}\right)_{4}{ }^{2+}$ 溶液の反応における反応種, 生成種の吸着・ 
脱離および表面反応がパラジゥム固体表面において LangmuirHinshelwood 機構にしたがって進行するものと仮定し，総括反応 の率速段階が反応生成物である $\mathrm{NH}_{3}$ の固体表面からの脱離課程で あると考えると(3)式および(6)式に基づく本反応の総括反応量論式。 すなわち,

$\mathrm{Pd}\left(\mathrm{NH}_{3}\right)_{4}{ }^{2+}+\mathrm{H}_{2} \rightarrow \mathrm{Pd}^{0}+2 \mathrm{H}^{+}+4 \mathrm{NH}_{3}$

に基づき，物質収支式は

$$
\begin{aligned}
& -\frac{\mathrm{d}\left[\mathrm{Pd}^{2+}\right]}{\mathrm{d} t_{\mathrm{R}}}= \\
& \frac{k^{\prime} K_{\mathrm{NH}_{3}}\left[\mathrm{NH}_{3}\right]^{*}}{1+K_{\mathrm{H}_{2}}\left[\mathrm{H}_{2}\right]+K_{\mathrm{Pd}^{2+}}\left[\mathrm{Pd}\left(\mathrm{NH}_{3}\right)_{4}{ }^{2+}\right]+K_{\mathrm{H}}+\left[\mathrm{H}^{+}\right]+K_{\mathrm{NH}_{3}}\left[\mathrm{NH}_{3}\right]^{*}}
\end{aligned}
$$

ただし，

\section{$k^{\prime} ;$ 速度定数}

$K_{\mathrm{NH}_{3}}$; 表面吸着 $\mathrm{NH}_{3}$ 吸着平衡定数

$\left[\mathrm{NH}_{3}\right]^{*}$; 表面吸着 $\mathrm{NH}_{3}$ と平衡する液相中 $\mathrm{NH}_{3}$ 濃度

$K_{\mathrm{H}_{2}} ;$ 表面吸着水素の吸着平衡定数

$\left[\mathrm{H}_{2}\right] ;$ 液相中水素濃度

$K_{\mathrm{Pd}^{2+}}$; 表面吸着 $\mathrm{Pd}\left(\mathrm{NH}_{3}\right)_{4}{ }^{2+}$ の吸着平衡定数

$\left[\mathrm{Pd}\left(\mathrm{NH}_{3}\right)_{4}{ }^{2+}\right]$; 液相中 $\mathrm{Pd}\left(\mathrm{NH}_{3}\right)_{4}{ }^{2+}$ 濃度

$K_{\mathrm{H}^{+}}$; 表面吸着 $\mathrm{H}^{+}$の吸着平衡定数

$\left[\mathrm{H}^{+}\right] ;$液相中水素イオン濃度

と書かれる。ここで, パラジウムイオン $\mathrm{Pd}\left(\mathrm{NH}_{3}\right)_{4}{ }^{2+} お$ おび水素 イオン $\mathrm{H}^{+}$の固体表面への吸着が物理吸着であるとみなし，

$K_{\mathrm{Pd}^{2+}}\left[\mathrm{Pd}\left(\mathrm{NH}_{3}\right)_{4}{ }^{2+}\right]<<1, K_{\mathrm{H}}{ }^{+}\left[\mathrm{H}^{+}\right]<<1 \quad \cdots(10)$ と考えると，(9)式は

$$
-\frac{\mathrm{d}\left[\mathrm{Pd}^{2+}\right]}{\mathrm{d} t_{\mathrm{R}}}=\frac{k^{\prime} K_{\mathrm{NH}_{3}}\left[\mathrm{NH}_{3}\right]^{*}}{1+K_{\mathrm{H}_{2}}\left[\mathrm{H}_{2}\right]+K_{\mathrm{NH}_{3}}\left[\mathrm{NH}_{3}\right]^{*}}
$$

と書かれる。ここで $\left[\mathrm{H}_{2}\right]$ と $P_{\mathrm{H}_{2}}$ の間に Henry の法則にしたがう 比例関係があるとみなすと $\left[\mathrm{NH}_{3}\right]^{*}$ と $P_{\mathrm{H}_{2}}$ の間には平衡関係が成 立するので,

$\left[\mathrm{NH}_{3}\right]^{*}=K_{1}\left[\mathrm{H}_{2}\right]=K_{1} \cdot H_{\mathrm{h}} \cdot P_{\mathrm{H}_{2}}$

ただし，

$K_{1} ;$ 比例定数

$H_{\mathrm{h}} ;$ Henry 定数

とおくことができ，(11)式は,

$$
\begin{aligned}
-\frac{\mathrm{d}\left[\mathrm{Pd}^{2+}\right]}{\mathrm{d} t_{\mathrm{R}}} & =\frac{k^{\prime} \cdot K_{\mathrm{NH}_{3}} \cdot K_{1} \cdot H_{\mathrm{h}} \cdot P_{\mathrm{H}_{2}}}{1+K_{\mathrm{H}_{2}} \cdot H_{\mathrm{h}} \cdot P_{\mathrm{H}_{2}}+K_{\mathrm{NH}_{3}} \cdot K_{1} \cdot H_{\mathrm{h}} \cdot P_{\mathrm{H}_{2}}} \\
& =\frac{k \cdot K_{\mathrm{NH}_{3}} \cdot K_{1} \cdot H_{\mathrm{h}} \cdot P_{\mathrm{H}_{2}}}{1+\left(K_{\mathrm{H}_{2}} \cdot H_{\mathrm{h}}+K_{\mathrm{NH}_{3}} \cdot K_{1} \cdot H_{\mathrm{h}}\right) P_{\mathrm{H}_{2}}} \\
& =\frac{k \cdot P_{\mathrm{H}_{2}}}{1+K_{2} \cdot P_{\mathrm{H}_{2}}} \quad \ldots \ldots \ldots \ldots \ldots \ldots \ldots . . . \ldots \ldots \ldots \ldots
\end{aligned}
$$

ただし，

$k ; k^{\prime} \cdot K_{\mathrm{NH}_{3}} \cdot K_{1} \cdot H_{\mathrm{h}}$

$K_{2} ; K_{\mathrm{H}_{2}} \cdot H_{\mathrm{h}}+K_{\mathrm{NH}_{3}} \cdot K_{1} \cdot H_{\mathrm{h}}$

と書かれる。

Fig. 12 は Fig. 11 における $T_{\mathrm{R}}=293 \mathrm{~K}$ および $T_{\mathrm{R}}=313 \mathrm{~K}$ の実 験結果に対する $k_{\mathrm{i}}$ (すなわち $-\mathrm{d}\left[\mathrm{Pd}^{2+}\right] / \mathrm{d} t_{\mathrm{R}}$ ) と $P_{\mathrm{H}_{2}}$ の関係を $k_{\mathrm{i}}{ }^{-1}$ (すなわち $\left.-\left(\mathrm{d}^{2}\left[\mathrm{Pd}^{2+}\right] / \mathrm{d} t_{\mathrm{R}}\right)^{-1}\right)$ と $P_{\mathrm{H}_{2}}{ }^{-1}$ の関係に書き改 めたいわゆる Langmuir プロットである。この結果から $k_{\mathrm{i}}^{-1}$ と $P_{\mathrm{H}_{2}}{ }^{-1}$ の間には直線関係が成立することは明白である。

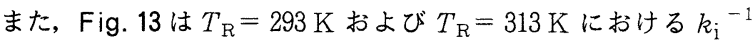
と $P_{\mathrm{H}_{2}}{ }^{-1}$ の関係におよぼすアンモニア添加の影響について示して いる。いずれの反応温度の場合もアンモニアが添加されると $k^{-1}$ 値および $K_{2} / k$ 值が上昇し，とくに $T_{\mathrm{R}}=293 \mathrm{~K}$ の場合に著しい。 このことは本溶液の総括反応の律速段階が固体生成物表面からの

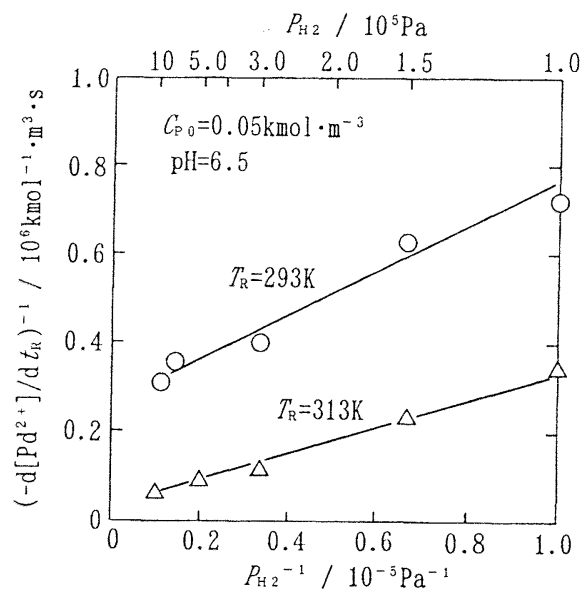

Fig. 12 Relationship between $\left(-\mathrm{d}\left[\mathrm{Pd}^{2+}\right] / \mathrm{d} t_{\mathrm{R}}\right)^{-1}$ and partial pressure of hydrogen $\left(P_{\mathrm{H}_{2}}\right)$ at $293 \mathrm{~K}$ and $313 \mathrm{~K}$.

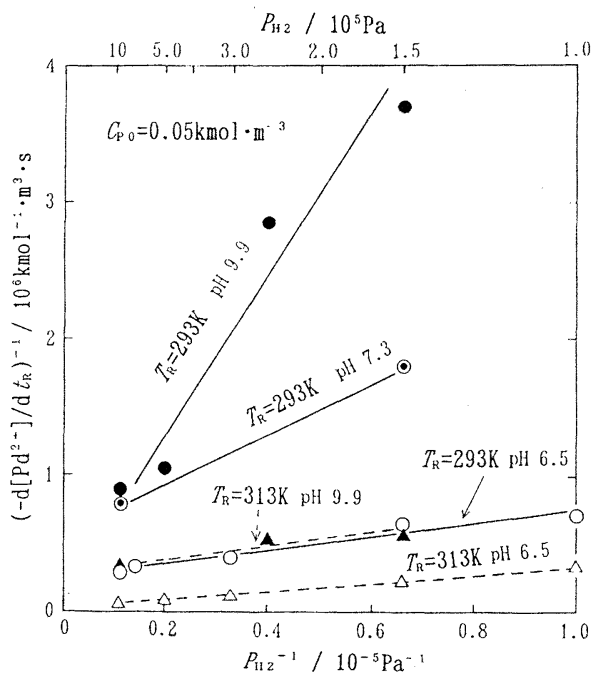

Fig. 13 Effect of $\mathrm{NH}_{3}$ additions on relationships between ( $-\mathrm{d}$ $\left.\left[\mathrm{Pd}^{2+}\right] / \mathrm{d} t_{\mathrm{R}}\right)^{-1}$ and partial pressure of hydrogen $\left(P_{\mathrm{H}_{2}}\right)$

$\mathrm{NH}_{3}$ の脱離であることを示唆している。

以上の結果から本実験における反応速度と水素分圧の関係は以下 のように整理される。すなわち水素ガス流通式回分反応装置では (13)式において,

$K_{2} \cdot P_{\mathrm{H}_{2}} \ll 1$

とおくと，パラジウムの還元反応量論式は,

$$
-\frac{\mathrm{d}\left[\mathrm{Pd}^{2+}\right]}{\mathrm{d} t_{\mathrm{R}}}=k \cdot P_{\mathrm{H}_{2}}
$$

と近似され, Fig. 6 および(5)式の結果と一致する。また, 水素加 圧式回分反応装置を用いて $P_{\mathrm{H}_{2}}$ が $1.0 \times 10^{5} \mathrm{~Pa}$ 以上で還元を行っ た場合はFig. 10(b) および Fig. 11 にも示したように反応温度が $T_{\mathrm{R}}=293 \mathrm{~K}$ および $T_{\mathrm{R}}=313 \mathrm{~K}$ と比較的低い場合, 反応の量論式 は(13)式で表現することができるが, 反応温度が $T_{\mathrm{R}}=333 \mathrm{~K}$ およ び $T_{\mathrm{R}}=353 \mathrm{~K}$ と高くなると Fig. 11 に示したように反応速度と水 素分圧の間には比例関係が成立する。これは反応温度が高くなると パラジゥム固体表面における吸着種の吸着平衡定数が小さくなるの で(14)式に示される関係が成立し, 反応の量論式は(15)式で近似さ れるあのと考えれば無理なく理解することができる。

\section{4. 結}

アンモニア性パラジゥム塩水溶液を試料溶液とし, 常圧水素ガス 
流通式および水素加圧式回分反応装置において, $293 \mathrm{~K} \sim 353 \mathrm{~K}$ の 温度範囲で, 水素分圧を $0.25 \times 10^{5} \sim 10.0 \times 10^{5} \mathrm{~Pa}$ として反応実 験を行い，本実験条件の範囲内で次の結果を得た。

1） アンモニア性パラジゥム塩水溶液中で $\mathrm{Pd}^{2+}$ は $\mathrm{pH} 6.2$ から $\mathrm{pH} 10.0$ の広い $\mathrm{pH}$ 範囲において $\mathrm{Pd}\left(\mathrm{NH}_{3}\right)_{4}{ }^{2+}$ として存在する。

2) 水素圧力が低い場合 $\left(1.0 \times 10^{5} \mathrm{~Pa}\right.$ 以下 $)$, 反応速度のパラジ ウムイオン濃度依存性は 0 次, 水素分圧依存性は 1 次となったが, 水素圧力が高い場合 $\left(1.0 \times 10^{5} \mathrm{~Pa}\right.$ 以上) は低い反応温度（293 K, $313 \mathrm{~K} ）$ において反応速度の水素分圧依存性が著しく低下した。 3）反応の活性化エネルギーは $41.0 \mathrm{~kJ} \cdot \mathrm{mol}^{-1}$ となり, Langmuir-Hinshelwood 機構を想定して実駼結果を整理したとこ ろ総括反応の律速段階は固体生成物表面からの $\mathrm{NH}_{3}$ (反応生成物) の脱離課程であるものと推定された。

謝辞本研究を遂行するにあたり塩化パラジゥム酸水溶液を貸
与して下さった田中貴金属工業(株)に厚くお礼申し上げる。

引用 文 献

1) Schaufelberger, F. A. : Journal of Metals, Vol. 8, p. 695-704, (1956)

2) Mackiw, V. N., Lin, W. C. and Kunda, W. : Journal of Metals, Vol. 9, p. 786793, (1957)

3) 中沢元一 : 電気化学, Vol. 28, p. 246-254, (1960)

4）安田拓夫・木内弘道・永井忠雄：資源之素材, Vol. 109, p. 523-528, (1993)

5）安田拓夫・木内弘道・永井忠雄：資源之素材, Vol. 109, p. 847-852, (1993)

6) Rasmussen, L. and Jorgensen, K. : Acta Chemica Scandinavica, Vol. 22, p. 2313-2323, (1968)

7) Seidell, S. and Linke, W. M. : Solubility of Inorganic and Metal Organic Compounds, Vol. 1, p. 1075 - 1079, (1958), American Chemical Society (Washington D. C.)

8）坂野武・永野健・寺田富士郎：日本鉱業会誌，Vol. 75, p. 469-473, (1959) 